\title{
A RACIAL-RELIGIOUS IMAGINATION: Syriac Christians, Iconic Bodies, and the Sensory Politics of Ethical Difference in the Netherlands
}

\section{SARAH BAKKER KELLOGG \\ San Francisco State University}

(D) https:/ / orcid.org/0000-0002-5394-5927

The icon sets the visible and the invisible into a relation with each other.

—Marie-José Mondzain, Image, Icon, Economy: The Byzantine Origins of the

Contemporary Imaginary

... race names a difference that emerges precisely in the context of evaluative hierarchies.

As the saying goes: now you see me, now you don't.

-Frantz Fanon, Black Skin, White Masks

Heleen confounds Dutch perceptions of Middle Eastern migrants with her long blond hair, vivid blue eyes, and provincial Dutch accent. ${ }^{1}$ She came to the Netherlands as a child in the 1980s, when her parents fled their mountain village to escape violent conflict between Kurdish separatists and the Turkish government. Like many other Syriac Orthodox Christians, or Suryoye, ${ }^{2}$ of her generation, she is deeply committed to her parish community, her extended family, and to speaking Surayt, also known as Turoyo, the endangered Central Neo-Aramaic language spoken in the monastery-studded highland villages of southeast Turkey. 
Every week, Heleen drives with her sister and cousin into the city of Enschede from Glanerbrug, their village on the Dutch-German border, to sing in church on Sunday mornings and to attend weekly madreshto, the church's evening classes on classical Syriac language and liturgy. One mid-summer's day, Heleen and I met for lunch at a bagel-shop-meets-café-terrace in Enschede's city center. As a place where one can study or talk undisturbed for hours, the café appealed to a certain class of urban Dutch cosmopolitans concerned with the quality of their cappuccinos and a taste for American-style baked goods. Eating our bagels and drinking our tea and coffee, we chatted cheerfully_-but our conversation soon turned glum as Heleen lowered her voice to a near whisper and began telling me about a number of upsetting recent interactions with some of her "ordinary," or gewoon (by which she meant "white") neighbors. Our conversation prompted a memory, which she recounted:

I had a friend from school, just an ordinary girl from the village, who said something to me once. You remember how we all go to the monastery to visit our dead in the cemetery on the day after Easter? You remember how many of us come - from all over the Netherlands and Germany - there are thousands of us. The street is full of cars and bikes and people - it gets very busy! Well, the day after, I met my friend on the street in Glanerbrug, and she started to complain to me about "all those Moroccans crowding up the street." I told her, "No! Those were not Moroccans! They were Syriac Orthodox people like me! I was there myself!" And then my friend said, "Ach, it is all the same." I could not believe she said that - the difference didn't matter to her at all!

Since 2007, I have heard or witnessed countless such stories while conducting ethnographic fieldwork among Syriac Orthodox Christians in the Netherlands. Friends, neighbors, and acquaintances have trouble registering the conspicuous Christianity that my research interlocutors put on display with their oversized gold cross necklaces, Jesus bracelets, and headscarves embroidered with images of the Virgin Mary. There is the story of the elderly man in Amsterdam whose neighbor asks him every year, for thirty years without fail, how Ramadan is going, and every year he responds: "I am not Muslim, remember? I am Christian, I don't celebrate Ramadan.” There are the students at the local secondary school where Syriac Orthodox youth are nearly as numerous as the white Dutch majority, and yet who were denied their request for accommodation for a major religious festival because 
they "were just given time off for the Sugar Feast [the three-day Muslim festival of Eid al-Fitr]." There was the moment the contractor finished erecting a giant cross at the entrance to St. Ephrem Monastery, and triumphantly presented it to the archbishop with the words, "Congratulations, Your Excellency-your mosque is finished!” My interlocutors would retell these stories with a laugh, but also a sense of injury. Amid their struggle with the intergenerational traumas of unrecognized genocide, dispossession, and displacement, these refusals to register Syriac Orthodox ethnoreligious difference stung. ${ }^{3}$ For scholars concerned with the damage done to Muslims and Christians alike by reductive binaries equating Europe with Christianity and the Middle East with Islam, these stories ask us to interrogate the role of race-thinking in constructions of religious difference in Western Europe.

Since 9/11, European debate over immigration and minority accommodation has often been framed as a matter of Islam's distance from Europe's putative Judeo-Christian ethical tradition, and therefore a matter of neither explicitly racial nor religious animus. For example, in an influential tract, former Pope Benedict XVI makes explicit what usually remains implicit in more liberal and secularist framings when he grounds the "moral-spiritual" foundations that distinguish Europe as an "autonomous cultural unit" in Incarnational theology, a Christologically specific theorization of personhood from which all ethics and politics flow (Ratzinger 2007, 43). In this formulation, human reproduction is inflected with theological significance, as the sexual, social, and spiritual formation of individual souls together comprise the Church, the Body of Christ in the world, whose historical inheritances separate a supposedly European ethico-political identity from other "autonomous cultural units" like the Islamic world, whose mere presence within Europe "cannot help but undermin[e] it" (Ratzinger 2007, 24).

In this worldview, theology undergirds ethics, and ethics undergirds culture. How then do we account for the claim by Heleen's school friend, echoed by many of her neighbors, that Syriac Christian difference is no different than Moroccan Muslim difference in the social imaginary of a Western European nation like the Netherlands, where the fraught relationship among Roman Catholicism, Calvinism, and liberalism has shaped a normative twenty-first century secularity? Why is it that in my research participants' accounts, it is skin, eye, and hair color, as well as accent, comportment, and other embodied traits, that register in their neighbors' attention, while visual symbols like crosses and tattoos of the Holy Familysymbols that could index a shared Christological "moral-spiritual foundation" — do not? What precisely is the nature of the difference perceived in these encounters? Approaching these moments of misrecognition from another angle, what does it 
mean that "Moroccans" and "Muslims" are invoked interchangeably throughout these stories? Given the ostensibly secular national context in which race and religion tend to be seen as separate ontological objects, what do we make of this collapsing of racial, national, ethnic, and religious histories in establishing which differences matter, and which ones do not?

I pursue these questions by examining a convergence of theological politics and semiotic ideology in constructions of sociopolitically salient difference in Western Europe, ${ }^{4}$ constructions conditioned by a common-sense, albeit complex, belief in the power of the body to communicate ethical difference. By ethics I mean, in the first instance, the criteria for judgment undergirding all human action and social relations. Michael Lambek's (2010) grammatical view of ethics as "intrinsic to speech and action," as geology is intrinsic to landscape (Lambek 2015), shares much with my own understanding of ethics, grounded in the anthropology of the senses (e.g., Seremetakis 1994; Stoller 1997) as shaped by intersensorial interaction, that is, the intimate exchange of sight, sound, and touch through which humans learn language from infancy. I take ethics as enmeshed in sites of social reproduction in that people generate, organize, and reproduce relations among selves and others through inherited evaluative hierarchies, which they may or may not re-examine as they proceed through life. ${ }^{5}$ As such, our intersensorial and social relations - the history of relations that form us as individual subjects - are imbued with power, reinforced by judgments. This understanding of "ethics" entails, in the second instance, relational differentiation of the sort that inscribes moral hierarchies onto unequal power relations. That is, perceptions of moral superiority ascribed not to individuals but to groups reproduce social hierarchies. Racialization, in this analysis, operates on the basis of heritable (in that it is socially reproduced) moral difference, rather than heritable biological difference. Considering that this racialization process, and such judgments, must be communicated to operate, I explore how a racializing regime of ethical differentiation plays out through everyday and bureaucratic misrecognition. In the Dutch context, ethical misrecognitions occur when the body communicates a relational history that challenges the autonomous, liberal ethical subject. More specifically, miscommunication arises when the perceiver refuses their own implication in the history of relations that makes the communication possible. I analyze this communicative process, and its breakdown, through the concept of iconicity.

An icon is a communicative sign in which a signifier resembles what it represents (e.g., a road sign with an image of a bicycle indicating the bicycle lane). Unlike symbolic and indexical signs, an iconic sign's meaning depends on connections 
among form, experience, context, and memory. In conversation with her friend, a central piece of who Heleen is and aspires to become in an ethical sense- that is, the evaluative hierarchy undergirding the communal practices she undertakes to rededicate herself daily, weekly, and annually to the liturgical life of her church and its ancestors - was obscured by her friend's inability to see these practices as anything other than social disruption, and thus fundamentally unethical - a violation of what is popularly called in Dutch normen en waarden (norms and values). In dehistoricizing Heleen's ethical life_-disarticulating its public form from experience, context, and memory in the very moment that she observed its social implications - her friend invoked the figure of the Muslim Moroccan body as a template for racial and religious differentiation and classification. In the same breath, she collapsed the complexity of Moroccan and Muslim ethnicities, ${ }^{6}$ religiosities, histories, and ethical lives by linking even minor disruptions of the social order to certain kinds of ethical embodiment. ${ }^{7}$ In this racializing regime, Moroccan Muslim and Syriac Christian bodies are made into icons of ethical difference through an iconoclasm that refuses to see the very relational histories that produce them as ethical subjects. At stake in this racializing regime is a question of reproductive power, which I understand as interpretive, material, and political control over sites of social reproduction - that is, the caretaking practices that socialize human persons into the body politic - a control that is implicated in but does not always entail sexual reproduction. Disputes between ecclesiastical and state authorities over reproductive power have shaped the history of Christian theological politics, and the secular political cultures influenced by them, since the first Iconoclastic Controversies in eighth-century Byzantium (Mondzain 2005).

In what follows, I examine one thread of the iconoclastic inheritance shaping a process of racial-religious differentiation and classification in the Netherlands in the obscured link between the ethical and the social. The outline of my argument is thus: In moments of racial-religious misrecognition, when Muslims are interpellated, in the Althusserian (1970) sense of the hail, as the archetype of ethical difference and Syriac Christians are hailed as either "Moroccan," as in this example, or as "Turkish" or "Muslim" elsewhere, the human body is read as an iconic sign to communicate an invisible difference. The constellation of form, experience, context, and memory that makes this meaning-making process possible constitutes a Dutch racial-religious imagination. The logic of the icon reveals an interplay of visibility and invisibility shaping Dutch perceptions of new minorities as ethically other when they take the human body as a vehicle of ethical communication while refusing to account for the history of reproductive relations that generate the 
body's form and bestow it with signifying power. I theorize this configuration of ethical thought, practice, and embodiment as "sensory politics" so as to further anthropological understandings of how race is "made and unmade in specific constellations" (M'charek 2008, 2013; M'charek, Schramm, and Skinner 2014; Balkenhol and Schramm 2019) rooted in "implicit colonial afterlives in everyday life" (Balkenhol 2014, 2016). The colonial afterlives of everyday life are especially pronounced in the enduring entanglement of reproduction and racialization, as Black feminist scholars have long shown (Mullings and Wali 2001; Bridges 2011; Davis 2019; Shange 2019). This entanglement problematizes the concept of freedom at the heart of the liberal ethical tradition and its theorization of personhood, which rests on a "false presumption that the right to choose is contained entirely within the individual and not circumscribed by the material conditions of the individual's life" (Roberts 2017 [1997], 309). ${ }^{8}$

One crucial dimension of my analysis derives from the fact that neither my interlocutors nor I ever intended to talk about race in our work with each other. And yet, it surfaced again and again in conversations during fieldwork for a project on diasporic Syriac Orthodox liturgical practices. As a novice ethnographer, I went looking for something I thought of as religion, not race; that I found complex "racial" formations embedded in conversations about "religious" life destabilized my own common-sense notions of my analytical categories. Thus the empirical material I offer only emerged as my interlocutors began to grasp my ambivalent relationship with Dutch national identity as a white (aspirationally ex-)Calvinist Dutch American researcher who had lived in the Netherlands as a child. Ethnographically, then, I examine moments that I either witnessed in person or had recounted to me by my interlocutors over the course of a decade, moments in which some perceived violation of the social order had registered in someone's attention as a "cultural" — and thus, by definition in the Dutch context, an "ethical" — difference. I argue that in Dutch common sense, "Syriac Christian difference is no different than Moroccan Muslim difference" because the state's distributed management of reproductive power among its minoritized subjects rearticulates Calvinism's iconoclasm. By erasing the relational histories, whether those of Moroccans or Suryoye, that produce subjects capable of ethical judgment or action, this iconoclasm subjects minoritized populations to a theological knot of an evaluative hierarchy, producing race and religion as inextricably entwined effects of ethical differentiation, classification, and control.

I develop this argument by tracing the interplay of visibility and invisibility in political and popular efforts to establish which differences matter across histor- 
ical, ethnographic, and bureaucratic domains, efforts that mark reproduction as the contentious center of sociopolitical life. I first elaborate "the racial-religious imagination" as an analytic for approaching the fraught relation between ethical life and reproductive power in Western Christian political history, tracing the generation of modern biological essentialism to long-running battles over heresy, "purity of blood," maternal embodiment, language, and the ethos of an ethnos. Then I sketch the theological, political, and temporal horizons of my ethnographic setting in the Netherlands; these horizons frame an ethnographic scene wherein Syriac Orthodox are misrecognized by the Dutch state's bureaucratic / social work / "minority integration" apparatus and are interpellated as Muslim. Using iconicity as an analytical tool, I unpack the shifting and unstable meanings contained within the Dutch concept of allochthony, a key tool of minority differentiation and classification that can, in different situations, link up with culture, religion, race, and/or ethnicity. Consistently at stake in these varying usages of the discourse of allochthony is an underlying effort to control sites of reproductive power in which the ethical inflects public conceptions of sociality, in effect politicizing and publicizing private morality. I conclude with a reflection on how background assumptions about personhood and materiality — that is, semiotic ideologies — shape the sensory and theological politics of racial-religious imaginations in ways that can either reinforce or destabilize both sovereign states and ethical subjects.

\section{A RACIAL-RELIGIOUS IMAGINATION}

To understand the intractability of racial thinking in postcolonial European imaginations, even in situations with religious difference ostensibly at stake, ethnographic perspectives rooted in political economy prove necessary but insufficient. Inchoate anxieties about access to the welfare state (cf. Geschiere 2009) or sentimental attachments to blood-and-soil metaphors of national or regional belonging that can be corroded by fast capitalism (cf. Holmes 2000) require an imagination primed to function as an interpretive frame for assigning criteria of inclusion or exclusion in destabilizing times. ${ }^{9}$ Such criteria, I contend, are unavoidably entangled with Christian theopolitics (e.g., McAllister and Napolitano 2020). As many scholars have pointed out, "religion is always operational in the study of race" (Husain 2017; see also Khan 2004; Hage 2010; Tamarkin 2014; Özyürek 2015; Khabeer 2017; Rogozen-Soltar 2017) in that several European Christianities furnished the moral reasoning required to perceive the embodied difference of non-Europeans as objects available for conquest, enslavement, and conversion. Historical scholarship on race, ethnicity, and ecclesial power has shown the extent to which these 
criteria emerge from imperial Christianity's fixation on the physical embodiment, territorial inscription, and social reproduction of heresy (Berzon 2016) in late antiquity. Out of this ancient repertoire, early modern Christians fashioned a theologically ordered "scale of existence," classifying the spiritual distance of racially marked bodies from divine power to legitimize the transatlantic slave trade, exclude Jews from sociopolitical life, and construct Muslims as civilizational threats (Arendt 2004 [1968]; Asad 2003; Jennings 2010).

Verena Stolcke (1993), reflecting on the intersection of gender and class in the European history of racialization, traces the global circulation of limpieza de sangre, the imperial Spanish Catholic doctrine of blood purity deployed against first Jewish and then Muslim converts to Christianity to deprive them of access to public and ecclesiastical office in the sixteenth century. In this discourse, a lineage with no Jewish or heretical antecedents signaled "purity," as blood became a vehicle of faith and then a marker of social condition. Mediating among imperial state, Catholic Church, and the fabric of sociopolitical life were the blood and milk of the maternal body, such that descent from heretics, Jews, or Muslims became a "permanent, indelible stain," a physical sign of original sin that naturalized unequal power relations (Stolcke 1993, 32). From this convergence of gender, sexuality, and class, anxiety over reproductive power circulated within and beyond Europe in a colonial communicative order that "operated through an 'episteme of resemblance' in which similitude dominated the organization of symbols and interpretations and representations of the universe" (Martínez 2008, 13). Here, anti-Semitism, Islamophobia, and colonial racism share joint descent from Western Christian theological anxieties, perpetuated iconically, about the relationship between reproduction and power. ${ }^{10}$ This global formation endures, setting the parameters for endlessly refracted variations contained within it.

Yet this period coincided with equally significant transformations of European understandings of religion and its proper role in organizing public life (Asad 1993; Connolly 1999; Markell 2003). As Anya Topolski (2018) has argued, theology serves as the horizon of past and present forms of racism in Europe, from anti-Semitism to Islamophobia. In this constellation, earlier religious categories ("Christians," "Jews," "Mohammedans," and "the Rest," e.g., pagans and polytheists) were transformed in the seventeenth and eighteenth centuries into philological categories (Hamito-Semitic, Aryan/Indo-European, Turanian, etc.), shifting the imagined locus of a people's essential, defining, hereditary ethos from a Scripture-based discursive tradition to language. Philology lent the category of Semite, which included Jews, Arabs, and Aramaic-speaking Christians of the Middle East 
(Gross 2020), a veneer of scientific neutrality that bridged earlier heresiological classifications with nineteenth-century scientific racism's putatively biological classifications, a racializing process that culminated in the Holocaust (Topolski 2018). Across these transformations, however, a theopolitical link between ethos and ethnos, an "imperial economy of Christian kinship” (Lukasik 2021), endured.

In grappling with the aftermath of World War II, the Netherlands turned toward a discourse of "norms and values" (Koning 2016, 173) in a public moral project to silence race and culturalize citizenship, reforging imagined connections among genealogy, culture, and the body as sites of power for producing ethical citizen-subjects capable of the independence of thought necessary to prevent another Holocaust. This moral project unfolded within a longer history in which relations among Dutch Calvinists and Roman Catholics shaped both the practice of secular political culture as well as four hundred years of Dutch slave trade (Kennedy 1995; Oostindie 2009), resulting in a sensory politics founded on theological questions of mediacy and immediacy posed by human bodies and religious icons alike.

A number of Europeanist ethnographers have identified what is often at stake in the sensory politics of racial and religious difference in Western Europe, as in Halleh Ghorashi's (2010) study of the pendulum swing between invisibility and hypervisibility of migrant women in the Netherlands, Mayanthi L. Fernando's (2014) study of the French state's "secular cunning" inciting Muslim women to make their supposedly private religious and sexual lives public, or Elayne Oliphant's (2020) study of Catholic art and architecture as the banal background of everyday life in France. In each of these cases, political secularism and cultural secularity reassert dominant religious norms at the expense of minoritized subjects by controlling what is visible and what is invisible in ever-shifting configurations. Only through this unstable push-pull effect can white and secularist Europeans construct a narrative of European identity as ethical. In her study of Dutch cultural amnesia around the slave trade and colonialism in Indonesia, Gloria Wekker (2016) links this push-pull effect to a racialized identity narrative she calls "white innocence."

The Orthodox Christian doctrine of the holy icon can aid analytically in making explicit the interplay between visibility and invisibility in these histories of racialization, ${ }^{11}$ drawing our attention to sites of reproductive power where invisible relations generate visible forms, which constitutes the process through which, in Christian Incarnational theology, an iconic sign becomes meaningful (Mondzain 2005). In the Dutch case, iconicity's theological undercurrents, historically submerged by the Protestant Reformation's iconoclastic suspicion of the materiality of meaning - that is, the problem of mediacy and immediacy — not only enable a 
variant of European racism but safeguard its continuing purchase in twenty-first century debates over immigration. This is because in post-Calvinist common-sense views of the body, it is difficult to speak directly about the ethical evaluation of embodied forms taking place in any given interpersonal interaction.

Syriac Christian encounters with the Dutch racial-religious imagination illuminate how post-Calvinist theological politics, in obscuring its own dependence on iconic thought, produces race and racial thinking by construing bodies as dangerous semiotic forms. In the Dutch politics of minority accommodation, Calvinist anxiety over the materiality of meaning meets liberal suspicion of the relationship between reproductive power and ethical life. As Kimberly A. Arkin (2013) argues in her study of the self-racializing practices of Parisian Sephardic youth, materialist liberal and secular understandings of ethnic identity obscure the centrality of maternal reproductive power in fashioning Jewish communal life. ${ }^{12}$ In the Dutch situation, the theological politics undergirding the tension between liberal and Calvinist understandings of reproductive power does not obscure the role of reproduction in ethical life so much as it ambivalently distributes responsibility for it over a network of state-funded social welfare organizations, as in the ethnographic situations I describe below, posing a set of ethical dilemmas for diasporic Syriac Orthodox whose desire for recognition is conditioned by the sociopolitical histories of non-Chalcedonian Christianity (e.g., Lukasik 2020).

\section{WELCOME TO THE WESSELERBRONX}

Known somewhat problematically among religious studies scholars as miaphysites (Bakker Kellogg 2018), Syriac Orthodox Christians partake of a Christological and liturgical tradition historically viewed as heretical by the Western (i.e., the Greek and then later Latin) Church. At the ecumenical councils of Nicaea (325 C.E.), Constantinople (381 C.E.), and Chalcedon (452 C.E.), imperial and ecclesiastical authorities sought to determine what part of the essence and personhood of Jesus Christ was divine, what part human, and what the arrangement of these parts might mean for Mary's relationship with the Creator (Syriac yoldath d'aloho, Mother of God), and thus for the nature of the relationship between visible humanity and invisible divinity. These were political questions as much as they were theological ones, in that they determined the proper dispensation of ecclesiastical and political power throughout the Byzantine Empire. Twenty-first-century anthropologists have largely ignored the lasting influence of this founding moment in the marriage of Christianity to empire on later European political structures, despite its influence on the ethnographic imagination itself, which as Todd S. Berzon 
(2016) argues, took shape in the heresiological writings of the third, fourth, and fifth centuries that identified genealogy and territorially emplaced peoples with anti-imperial heresy (see also Buell 2005). This was the period during which Syriac Orthodoxy emerged as an ethnic church in Patristic writings - the Suryoye 'atiqe, "the ancient Syrians" (Weltecke 2016), who were ethnically Syrian (also referred to as West Syriac) because of their non-Chalcedonian theological difference. They rejected the proceedings of the Council of Chalcedon and the language of its definition of Christ's dual incarnate nature, along with those congregations who would eventually identify as Coptic, Armenian, Ethiopian, and Eritrean Orthodox-although there is reason to believe that the original disagreement was largely grammatical, political, and linguistic-cultural rather than substantively Christological. One crucial outcome of this battle over the sociopolitical valence of heresy was the expulsion of West Syriac-speaking congregations, many of whom took refuge in Persia and, later, in the Islamic caliphates, where centuries of dialogue with Jewish, Muslim, and East Syriac (i.e., the Assyrian Church of the East) left marks on Syriac Orthodox thought and practice (e.g., Griffith 2008).

Since the nineteenth century, multiple waves of violence have spurred global Syriac Orthodox migration, leading to new diasporic formations (Atto 2011; Armbruster 2014; Mack 2017; Jarjour 2018; Schmoller 2018; Kiraz 2019; Hager 2020). Since the 1970s, according to diocesan estimates reported to me orally, at least twenty-five thousand Syriac Orthodox Christians have settled in the Netherlands, especially in and around the cities of Enschede and Hengelo in the easternmost region called Twente. While they remain largely unknown to the rest of the country, Syriac Orthodox are visible enough as an ethnocultural group in Enschede to merit dedicated liaison officers both in the municipal government and in the local police force. In the suburb of Wesselerbrink, they comprise the largest minority group in the district, which many young Suryoye of my acquaintance call the WesselerBronx, in playful reference to U.S. American histories of racialization, immigration, and cultural production.

While disparate national histories of secularization throughout the Middle East have created regional differences among Syriac Orthodox self-understandings (Bakker Kellogg 2015), diasporic Suryoye have nonetheless maintained a tight grip on collective memories of non-Chalcedonian history as the authorizing wellspring of ethnonational difference, whether defined as Assyrian, Aramaean, or just Syriac (Bakker Kellogg 2019). How they labor to make this non-Chalcedonian Christianity relevant to the programs meant to integrate them into Dutch society holds a mirror to the logics at work in European debates over minority accommodation. 
In the Netherlands, they are charged by both the state and by their neighbors with adapting to Dutch norms and values in ways that, intentionally or not, target obligatory features of Syriac Orthodox Christian ethical tradition. ${ }^{13}$

Organizing this national project for minority integration for much of the late twentieth and early twenty-first centuries is a distinctively Dutch conception of allochthony, which until 2017 was an official state category used by bureaucrats and social workers to denote residents and citizens of "non-Western" descent (Reekum and Duyvendak 2012). Derived from the ancient Greek allo-, meaning "other," and chthon-, meaning "earth," een allochtoon is a person who lives permanently in the country and may even have been born to parents whose own parents were born in the Netherlands, but who is understood to be visibly marked as descended from a non-Western part of the world (Schie 2018). This visible mark is rooted in an explicitly religious understanding of territorial belonging: as early as 1959, a government report for the southern province of Brabant used the word allochtoon to refer to Dutch workers migrating from the northern provinces, highlighting the religious and economic difference of these mostly Protestant, middle-class migrants from the mostly Catholic, working-class southerners among whom they settled. The essentialist discourse of allochthony, according to Dvora Yanow and Marleen van der Haar (2013, 246-47), has deep roots in ancient Hippocratic thought, basing "differentiations among persons and groups on 'socioeconomic and cultural differences" tied to place and behavior. Whether a subgroup was designated allochthonous depended on perceptions of their relative likelihood to integrate into a social fabric whose local organization fell along sectarian lines. While in some respects these sectarian lines have since been subsumed within a secular ethics of cosmopolitan nationalism (Lechner 1999, 2008), ${ }^{14}$ many commentators nonetheless claim this cosmopolitan nationalism as a major achievement of the so-called Judeo-Christian ethical tradition that was, as Pope Benedict XVI reminds us, produced in large part by political tension between European Protestants and Catholics. And yet my interlocutors' Christianity, it turns out, proves insufficient to ensure smooth assimilation into this tradition, as the following story demonstrates.

\section{“LIVING BETWEEN TWO 'CULTURES"}

One of the moments in my fieldwork when I first discerned the sensory and theological politics undergirding Dutch anxieties over new minorities' norms and values took place one Saturday afternoon in 2010, when the niece of the abbott of St. Ephrem Monastery organized a public lecture and panel discussion titled "Living between Two Cultures." The expert panel included an alderman from the city 
of Enschede, a police officer responsible for liaising with the Syriac Orthodox community, a Syriac Orthodox jurist working in Amsterdam, the monastery's resident theologian (who happened to be a convert from Roman Catholicism), and a senior researcher from a nonprofit policy, research, and training organization located in the faraway city of Utrecht. This researcher, one Dr. K, was the keynote speaker of the event; it was her speech, and her audience's outraged response to her words, that began to trouble my understanding of the boundaries between racial and religious discourse in my field site. Dr. K introduced herself to the at-capacity crowd as an academic criminologist and professional expert in social pedagogy. ${ }^{15}$ As the "Interculturalization" project leader at a youth care [Jeugdzorg] organization's study center on migrants and refugees, she had been invited by the abbott's niece to address their community's growing problem with young Syriac boys causing trouble on the streets of Enschede. These "menacing" [straatkwaad] Syriac adolescents were a growing problem for criminologists, she said, and she was there to help the community understand the behavior of what she called "these so-called street terrorists." She informed her audience that the roots of young male Syriac aggression were as much "cultural" as they were "social" and "psychological." Based on studies conducted by her organization among Turkish, Moroccan, and Surinamese youth in the cities of central Holland, she explained that it had been scientifically established that young migrant boys were susceptible to developing a problematic image of masculinity defined by a lack of empathy, which could lead to problems with drugs, alcohol, the wrong friends, and eventually street violence. The source of this unhappy version of masculinity, she explained, was the "coercive dynamic" of many "allochthonous" families.

In her "Living between Two Cultures" lecture, Dr. K explicitly hailed her Syriac Orthodox audience as allochtonen. Their families were not alone, she told them, in experiencing problems with physical and verbal abuse, but the susceptibility of their young men to grow into the criminal element had everything to do with cultural resistance to receiving expert help from pedagogues, social workers, psychologists, and other professional caregivers [zorggevers]. She admitted that while some other experts claimed lack of integration as the cause of criminality among allochthonous communities in the Netherlands, she believed that the source of the trouble lay with the uneven process of emancipation from their traditional norms and values, causing intergenerational conflict within families and communities. Without specifying what kind of norms and values she meant, she explained that "Moroccans are much too quickly integrated," while "Turks remain more isolated and subject to social control within their communities, so that the emancipa- 
tion process leads to family conflict." The real problems arose, she said, when families did not avail themselves of the support offered by youth care organizations. Addressing the audience with emphasis on the hybrid Dutch-English phrase, "Er is absoluut geen case management" (there is absolutely no case management), she began to plead: "Let the professional caregivers do their job - let them intervene in all the problems that arise in your family! They have specially trained caregivers for every member of the family, many from the same ethnic group, who can act as a go-between with the relevant care organizations; please, make use of them!”

By the end of her speech, the churning anger in the room was palpable. Her audience was appalled. The question-and-answer session did not go well — at one point, with an embarrassed laugh, Dr. K admitted that she could not understand the provincial Twents accent of many of her questioners, which did little to soothe the crowd's disquiet. Their questions betrayed varying degrees of indignation and skepticism: "We are not the ones who need to hear this - and the people who need to hear it would not come to something like this anyway!" "We are not Turks, we are not Moroccans, we are not Surinamese! What does any of this have to do with us? How can you come speak to us without knowing the first thing about who we are?" One audience member of my acquaintance, a trained schoolteacher from Syria named Farida, raised her hand to comment: "You cannot deny that more and more there are 'black' schools and 'white' schools. Discrimination and exclusion really happen here, and that makes it hard for people like us to even want to integrate. It would make a huge difference if Dutch people could work on integrating themselves a little too [een beetje mee integreren]!" A rare moment of audible approval and visible head-nodding occurred when the monastery's resident theologian spoke up to ask the panel: "So why have we not asked the most important question of all yet? What does it mean to be a Christian in all of this? We are having this meeting in a monastery for a reason!" But in spite of the audience's applause at his intervention, the panel discussion veered off in another direction. After the meeting ended, I asked my friends and acquaintances what they made of it, and they shared a general sense of the event as a failure.

From where I was sitting, the encounter between the criminologist and her audience began to unravel when Dr. K named "culture" as the source of young, male Suryoyo criminality. While pathologizing culture constitutes a familiar strategy of colonial power the world over, the Syriac Orthodox audience in that moment reacted to Dr. $\mathrm{K}$ diagnosing the problem with their supposed culture as the "coercive dynamic" of "allochthonous" family life. While her characterization of Moroccan, Turkish, and Surinamese family life as culturally deficient 
was troubling enough, the audience's outrage at having their family lives hailed as culturally indistinguishable from that of families from other backgrounds was inflamed by their understanding that it was their liturgical tradition - their "culture" and its "norms and values" - that had brought them all together for this meeting in the first place. Here, the reader might reasonably wonder whether the audience's response was not a classic "model minority" refusal of solidarity with other marginalized groups to secure for themselves the privileges of closer proximity to whiteness. This would make for a plausible explanation had not so many of my interlocutors been preoccupied with safeguarding their ethical difference as a recognizable form of ethnic difference in opposition to their secularist and Western Christian Dutch neighbors. Given their insistence on publicly flouting the expectations of Dutch model minorityhood whenever the obligations of Orthodox liturgical life demanded it, even when it came at a social cost, I suggest that the primary source of their outrage lay elsewhere, in the desire to adapt the tools of Dutch social work to non-Chalcedonian liturgical theology, and to have that theology recognized as sociopolitically salient by municipal and national authorities. Much like Heleen's friend in the village, however, Dr. K worked within a discourse in which cultural, ethical, religious, national, and ethnic differences were effectively synonyms - as evidenced by her vagueness about what, precisely, any of her research subjects needed to be "emancipated" from-leaving her no frame of reference for integrating non-Chalcedonian theology into the category of allochthony, much less discerning the kind of ethical demand it might make of her audience to violate Dutch normen en waarden. Instead, she identified Syriac Orthodox difference with Muslim difference, which she, in turn, constructed as a psychological problem to be solved by surrendering "traditional" parental authority over individual socialization to the state. For the Syriac Orthodox in the Netherlands I work with, "traditional" parental authority over the reproduction of individual and communal socialization is grounded in a soteriological (i.e., salvific) system in which kin relations are integrally and intimately intertwined with ecclesiastical authority and monastic life. ${ }^{16}$ For my interlocutors, Dr. K's suggestion that they surrender authority over family life to secular social workers stabbed a dagger in the heart of their efforts to innovate theologically acceptable configurations of liturgically ordered family life in a Dutch context.

The "Two Cultures" confrontation rearticulated two long-standing questions in Dutch political history: (1) Who is responsible for the reproduction of social life? one of the key controversies bedeviling nineteenth- and twentieth-century negotiations between Calvinists and liberals over the role of the family and of religious 
education in mediating a child's relationship with the state (e.g., Kuyper 1943), and (2) Who mediates relations among competing sites of reproductive power? Here, reproduction and mediation constitute mutually entangled theological problems. In the process of forming the modern state, Calvinists and liberals worked out their theological differences through an institution called verzuiling, or "pillarization," a rigid, vertically organized, and self-reproducing system of segregation among Protestants, Catholics, liberal humanists, and, later, socialists that is widely understood to have ended in the 1960s, although scholars have noted pillarization's lingering structural legacies (Bracke 2013; Blom and Talsma 2000). The Calvinist-led movement to maintain boundaries between religious and comparable ideological blocs developed throughout the nineteenth century as part of a backlash against French Enlightenment values, an effort itself linked to resentment against Napoleonic incursions into the Low Countries. Never a formal doctrine of state per se, pillarization resulted from compromises in which differences across the populace were not to be transcended through individualistic, abstract citizenship as in secular liberal regimes, but rather by crystallizing those differences into self-reproducing corporate entities. When the constitution was reformed in 1848 to formalize the separation of church and state, Calvinists insisted that religious institutions mediate the integration of new groups of citizens into public life.

Central to these debates was the status of schools and families: should, as the liberals demanded, a secular authority oversee the relationship between children and society, or should parents? For Abraham Kuyper (1943), the nineteenth-century architect of Dutch political Calvinism and the founder of the Anti-Revolutionary Party (ARP), the father stood as the mediator of a family's relation with the state because his authority within the family structure mirrored that of the earthly Church's relation to the Holy Trinity; rooted in the primal blood relation, the family formed the basis for all human social relations. In my interpretation, Kuyper's Christian political philosophy rested on an implicit logic of iconicity: the relation of iconic resemblance inspired by divine providence communicates a family's holiness directly to God. Dutch liberals, unsurprisingly, strongly rejected the premise of such an arrangement. To resolve the impasse, the ARP formulated the principle of souvereniteit in eigen kring, "sphere sovereignty," the same political theology used by white South African political elites to justify racial apartheid. In this system, liberal humanism and socialism constituted pillars of communal difference commensurable with the religious difference of Catholics and Protestants, and boundaries were maintained as much by private kinship practices like marriage endogamy and exclusive burial grounds as by public-facing institutions such 
as denominational schools, newspapers, labor unions, and drinking establishments. In state-funded denominational schools especially, religious authorities gained significant power over how children were taught. While this tension between Dutch Calvinists and liberals created the structural conditions through which new minorities must find their way into Dutch social life, it also created a set of concepts through which they know and are known by the state and their neighbors. As I show in the following section, these theologically grounded concepts produce racializing effects because, while currently clustered into the word allochtonen, they fundamentally concern themselves with the questions of ethical relatedness, reproduction, and differentiation/classification on which earlier controversies over schools and families turned.

\section{THE SHIFTING FRAMES OF ALLOCHTHONY: Culture, Ethnicity, Religion, Race?}

One reason the Syriac Orthodox audience felt such frustration with the criminologist that day at the monastery was what they saw as a missed opportunity to talk through with each other what was meant, and what was demanded, by the "two cultures" referenced in the event's name. Bedeviling their efforts to know and make themselves known to the Dutch state and their neighbors was a contentious debate over which metacategories properly applied to being Syriac Orthodox in the Netherlands. The term culture was often privileged in these conversations because it accommodated my interlocutors' diverse political aspirations; culture functioned as a polysemic container for a host of differences deemed politically salient enough to garner disciplinary attention (and thus funding for community programs) from the state. My friend Meryem, for example, pointedly used the Dutch word kultuur over and against the term religion when she told me, "we are not just religious. Syriac Orthodoxy is a culture." Meanwhile, a Dutch-Syriac anthropologist friend, objecting to scholarly definitions of Syriac Orthodoxy that reduce it to an "ecclesial community" used the Dutch word volk (people; ethnic group) to insist that "just because we gather in a church does not mean we are not a people in a political sense.” And yet, despite culture's strategic value, it also silenced Syriac Orthodox efforts to convey the sociopolitical salience of their non-Chalcedonian Christianity. In this silence, the question of race lurked awkwardly at the edge of our attention. Race was an unwelcome problem no one quite knew what to do with, but a problem nonetheless, as conversations died and facial expressions closed up whenever the subject veered toward communal relations with white Dutch neighbors. It took many years for me to make sense of race's unspeakabil- 
ity in these situations, except for uncomfortable references to "black schools" and "white schools," until I came to discern its roots in the ethical demands of Dutch cosmopolitan nationalism.

Twenty-first-century Dutch cosmopolitan nationalism is today explicitly staked on the public discourse of normen en waarden, reasserted by Prime Minister J. P. Balkenende in 2002 in an effort to restabilize Dutch social relations after the assassination of the anti-Islamic provocateur and politician Pim Fortuyn. In silencing race, Dutch cosmopolitan nationalism links perceptions of public-facing, politically salient ethical difference to the category of culture; as a category, the latter invites a particular kind of engagement with the state and its funding programs (cf. Duyvendak, Geschiere, and Tonkens 2016; Mepschen 2016). This partially accounts for why Meryem and other Syriac Orthodox explain their commitments in culturalist terms: their ethical obligations as Orthodox Christians are communal, "public," and political as well as individual, "private," and spiritual, and they thus require the engagement of interested outsiders like the municipal government to secure spaces in which to reproduce these ethical commitments. And yet the durably racializing logic of culture is evident in the ambiguity it generates, particularly among public commentators who explain social friction in terms of Islamic norms and values, as in this opinion piece by Dirk Vlasblom published in November 2017 in the national center-left newspaper NRC Handelsblad for an online feature called “Dossier: Racism”:

There is some confusion in the heated Western debate over migration. Newcomers tend to call every expression of discontent with their arrival and every form of discrimination "racism." This is incorrect. The fact that application letters signed with Islamic sounding names are often ignored is not a matter of racism. The applicant is discriminated against for his/her culture or religion, not on the basis of appearance, like skin color, eye shape, or hair type. (Vlasblom 2017; translation by author)

Here, the journalist insists on distinguishing between perceptions of religious difference signified by a person's name and the perception of some unnamed difference signified by a person's phenotype, as if cultural/religious identity were in no way embodied, material, or relational. What Vlasblom thinks "skin color, eye shape, or hair type" signifies in a racist schema is left unexplained, but his writing invokes a sensory politics of its own, one that differentiates among varieties of visuality in the interplay between visibility and invisibility, such that a written name 
signifies what the unseen body cannot: a genealogical, and therefore an embodied, material, and reproductive relation to intolerable ethical difference.

What remains unexamined in commentary such as Vlasblom's is why new minorities in the Netherlands, especially those from the Middle East and North Africa, might think of themselves as subject to racist discrimination in situations where only their religious or cultural background is perceptible in the first place (see also Özdil 2014). It is because, in insisting on the body's invisibility in a chain of reasoning that infers Islamic difference from a job seeker's family, in turn inferred from a job seeker's visible name, the journalist elides how any inference drawn from names, religions, cultures, nationalities, and families is possible only by taking these as iconic of an embodied relationality in the first place. Ethical difference, whether named "cultural" or "religious," is inferred through the logic of reproduction, genealogy, and inheritance. This makes for a mode of reasoning grounded in iconic thought: the signifying practice (a name) constitutes the relation that it signifies (genealogy). But - and this is the crucial part - the author disavows the relationality to which he obliquely refers in the very process of referring to it. Culture produces race by erasing the historical social relations - the reproductive powers - through which "old" and "new" European subjects were formed in relation to each other through globalized processes of colonial domination, missionary work, labor migration, trade relations, and economic extraction.

To return to the question of terminology, however, Syriac Christianity does not technically exist in Dutch legal-bureaucratic terms, and so in the state's management apparatus, their perceived differences are yoked to an ethicized perception of Muslim difference. Bureaucratically, the state has formulated "national origin" into a signifier of "allochthonous norms and values," which it then renders into a biopolitical category called religion. This process becomes evident in documents like the WRR's (Scientific Council for Government Policy) 2004 report by Gabriel van den Brink, titled "Sketch of a Civilization Offensive: On Norms, Normalcy, and Normalization in the Netherlands," providing insight into the categorical collapse of ethnic, national, religious, linguistic, and racial histories in Heleen's high school friend's reference to "Moroccans" as the archetype of ethical otherness. In section 4.3, devoted to "Migrants and Modernity," the author explains his approach to analyzing the differences among citizens of migrant descent:

In the past few years there has been increasing debate over whether these ideas hinder successful integration. I rely on a survey taken among a large number of allochthonous citizens in the Netherlands in 1998. This survey 
distinguished between five groups: Turks, Moroccans, Surinamese, Antilleans, and authochthonous citizens. Because the differences between Turks and Moroccans are minimal, I will treat them as a single category and refer to them as Dutch citizens with an Islamic background. (Brink 2004, 110; emphasis original)

Although no longer an official category, in everyday conversation allochthony remains a powerful tool of ethical differentiation, classification, and control in how it evokes a kaleidoscopic sensory politics with both spatial and temporal dimensions. Spatially, it refracts perceptions of difference across shifting boundaries of north/south and east/west as it extends to Eastern Europeans, especially those from Poland, as well as to people from Africa and the Middle East. At the same time, allochthony works in a temporal dimension to produce religion as an artifact of a past that the Dutch allegedly overcame when they dismantled pillarization. Allochthony embeds a religious imaginary-religion-as-atmospheric-museum-piece — within an embodied ethic of secular emancipation, which for many makes for a defining feature of twenty-first-century Dutch cosmopolitan nationalism. And yet Calvinist theocratic norms persist in this embodied ethic and aesthetic atmosphere. Nineteenth-century notions of "'personal self-discipline' as well as collective moral control" (Stoler 1995, 119) circulate in twenty-first-century common sense about how to properly orient one's life trajectory toward the pool of collective energy that sociologists Yannick Coenders and Sébastien Chauvin (2017) call Dutch "emotional democracy," forming subjects who might engage religious music, architecture, and church bells aesthetically while policing the reach of more ethically demanding sensory forms like the daily Muslim call to prayer (e.g., Tamimi Arab 2017, 111-49). Thus Dutch cosmopolitan nationalism demands that citizens of color accommodate white sensibilities to ensure that the Netherlands remains an ethical, "anti-racist" society_-because ethics, in liberal tradition, is marked by reflexive freedom from tradition. For Dr. K, this entailed allowing social workers to "intervene in every part of family life" to correct parents when they were not appropriately socializing their children according to Dutch norms and values to be independent thinkers. Every "axis of othering" (Koning 2016) that allochthony touches, it touches so as to assert interpretive control over sites of reproductive power, whether social pedagogy, job applications, community funding programs, genealogical practices, mosque-building projects, or indeed, raising children, where the formation of ethical subjects intersects with public sociality. 


\section{SOVEREIGNTY, ETHICS, AND THE REPRODUCTIVE FUTURE}

Structuring Dutch cosmopolitan nationalism's moral project, in which disparate sites of reproductive power generate the ethics that bring about sociality, is a set of background assumptions about materiality and personhood that shape communicative practice, what linguistic anthropologists call semiotic ideology. One key feature of a Calvinist semiotic ideology, reinforced in the colonial missionary encounter (Keane 2007), is the "dematerialization of meaning" that contains a seed of ambivalence over the inescapable materiality of all communicative practice, whether linguistic or extralinguistic. Calvinism mistrusts materiality; human persons are persons because they communicate without mediation. This ideal of immediacy, of direct communication without relying on intermediary sensory forms to transmit or facilitate the connection between human persons and God, and thus between persons and other persons, constitutes a hallmark of Calvinist-inflected varieties of secularity. This dematerialization of meaning divorces secularist Dutch responses to religious aesthetics from any sense of ethical demand. The seed of ambivalence reaches a crisis point, I suggest, when confronted with the human body as semiotic form — not in the sense of an "expressive" form, but as the durable outcome of the history of reproductive relations that produced a person. In Calvinist semiotic ideologies, a person may intentionally express themselves through their body in a way that demonstrates their agentive self-mastery, as with the normative Calvinist family's mimesis of the Holy Family, but a perception of danger appears when the body communicates not the intentional spirit of the person inside, but invisible forces beyond the person and their intentions. This marks the ever-recurring crisis of Christian iconoclasm since the seventh century: all bodies are formed through the history of social relations that precondition any person's individual capacity for self-mastery, a capacity that the modern liberal tradition identifies with ethics as long as a person can prove their independence from those relations when deciding how to act.

In a twenty-first-century Calvinist semiotic ideology, and in the ethical regime staked on it, confronting the postcolonial history of reproductive relations communicated by the bodies of others disrupts the story of ethical self-mastery. "Race," according to philosopher J. Reid Miller (2017), is the name "we" (in this case, white Euro-Americans) bestow on our perception of persons whose histories we cannot assimilate into our own self-image while remaining intelligible to ourselves as ethical subjects. In the twenty-first century, this makes for a characteristic problem of whiteness-as-sociopolitical-formation and of imperial Christianity, linked by a global political economy built on slavery and colonial extraction. 
The descendants of missionaries, colonizers, and slave traders mark others as ethically different to remain stable ethical subjects to themselves. This move requires a unique interplay of visibility and invisibility: I must erase that part of my history that I share with you, a history that produced both of us, to mark you as visibly, ethically, distinct from me. This is not a universal habit of thought. Its condition of possibility is that it partakes of the logic of iconicity while denying it. An Orthodox understanding of iconicity, on the other hand, acknowledges that all forms are semiotic, in the sense that they communicate because their material existence results from a history of socially significant relations of reproduction. Whether the human body or a painted icon of Christ, everything that exists in material form takes its shape via a relational act of divine creation or human reproduction - where the invisible intersects the visible. On one end of the Christian imagination, Orthodox semiotic ideologies acknowledge the icon's ability to materialize the relationship between viewer and invisible power, the history of relations, that produced both the icon and the viewer as intimately interconnected parts of an Incarnational economy (Mondzain 2005). In a Calvinist-inflected theological politics, such acknowledgment can prove difficult. This means that, in addition to everything else it does, racism is the denial of the history of relations that have made us all who we are, and a denial of the invisible forces of reproduction that generate our material and ethical existence. In this view, the materiality of the body communicates these histories of reproductive relations because it is an outcome of these histories, making the invisible "history of responsibility," which Miller (2017) identifies as the implicit link between race and ethics in European philosophical tradition, perceptible. In this sense, as Eboni Marshall Turman (2013) argues, racism is constituted through unequal power relations originating in the theological failure to recognize that Incarnational economy through which persons are formed relationally. This is where the dematerialization of meaning can lead - to a sensory politics dedicated to obscuring the history of reproductive relations as a tool for asserting interpretive control over future sites of reproductive power.

With this in mind, consider again Heleen's misrecognition by her friend on the streets of Glanerbrug. I, too, have attended the day-after-Easter festivities at the monastery and have seen for myself the vocal outrage expressed by Dutch passersby at the monastery's chaotic crowd control and diminished capacity to operate according to Dutch conventions of regulating public space. Although their passage by the monastery was only briefly delayed, I observed the voluble irritation of numerous cyclists and drivers shouting at the devout coming to honor their dead, calling them "ridiculous" (belachelijk) in outraged tones that struck me as 
out of proportion to such a minor inconvenience. Although Dutch-born Suryoye often speak of themselves as "model minorities," their liturgical obligations, especially where they concern ancestors and kin relations, tend to take precedence over other concerns, and will often prompt public displays of ritual mourning that transgress local Dutch norms, such as spontaneously processing by foot and en masse through city streets to attend a funeral Mass. Their neighbors find the collective affective dimensions of such liturgical obligations inscrutable, my interlocutors tell me, because "even our Roman Catholic friends are so Calvinist in how they think and act that they have forgotten how to be Christian."

For Syriac Orthodox Christians in the Netherlands, what is seen and what remains unseen, what registers viscerally in their neighbors' impressions of their difference and what escapes attention entirely, illuminates a race-producing evaluative hierarchy. This hierarchy emerges from a history of contested interpretive control over sites of reproductive power, the formation of ethical subjects, and their interface with public sociality. As an outcome of Calvinist-liberal compromise, this theological politics bureaucratizes European Christian ambivalence toward the communicative and reproductive power of the human body/icon. The religious icon offers an analytical tool for making sense of this ethical economy, in which the anxieties provoked by encounters with bodies-deemed-heretical draw attention to the crux of the matter: conflicting views of sovereignty over the reproductive future. The body/icon threatens to destabilize the sovereignty of states and subjects because it shows us where past becomes future, now, in the present, whether we will it to or not.

\begin{abstract}
Since 9/11, political debate over immigration in Europe is often posed as a question of Islam's distance from Europe's putatively Judeo-Christian ethical tradition - and therefore a matter of neither explicitly racial nor religious animus. This article interrogates this claim from the perspective of Syriac Orthodox Christians living in the Netherlands, who, despite their conspicuous Christianity, are frequently told by both the state and their neighbors that their ethnoreligious difference is not meaningfully different from Muslim difference. Drawing on fieldwork in the Dutch subprovince of Twente, I analyze both everyday and bureaucratic moments of misrecognition as sites of racialization that illuminate a Dutch racial-religious imagination rooted in post-Calvinist theological anxieties over social reproduction. By showing how minoritized bodies are read as icons of invisible reproductive relations, I deploy the Orthodox Christian doctrine of the holy icon to theorize secular modern racialization as a
\end{abstract}


process of ethical differentiation, classification, and control over reproductive power. [Europe; race; ethics; semiotics; immigration; Christianity; Islamophobia]

\section{NOTES}

Acknowledgments As always, my first and deepest thanks go to my friends and research participants among the Syriac Orthodox Christian community in the Netherlands whose kindness, honesty, and vulnerability have transformed me and this work in ways both visible and invisible. While I cannot do justice to this article's full relational history here, this work was formed in conversation with many people, especially Mor Polycarpus Augin Aydin, Susan Ashbrook Harvey, Melissa L. Caldwell, Don Brenneis, Carolyn Martin Shaw, Susan Harding, Danilyn Rutherford, Mayanthi Fernando, Megan Moodie, Naures Atto, Noah Tamarkin, Kimberly Arkin, Aisha Khan, Esra Özyürek, Charles Hirschkind, Christina Robinson, Heleen Murre-van den Berg, and the participants of the 2018 Orthodoxy in Transition Workshop at the Institute of Eastern Christianity, Radboud University in Nijmegen. I am also grateful to Heather Paxson, Brad Weiss, Christopher Nelson, and the anonymous reviewers of Cultural Anthropology for their crucial insights and generative feedback. Various stages of research and write-up were made possible by the Social Science Research Council's International Dissertation Research Fellowship, the Wenner-Gren Foundation's Dissertation Fieldwork Grant, and the Hunt Postdoctoral Fellowship, the Woodrow Wilson Foundation's Charlotte W. Newcombe Dissertation Fellowship, a preliminary fieldwork grant from UC Berkeley's Institute of European Studies, and a visiting scholar residency at the Berkeley Center for the Study of Religion. Finally, this piece would have been nearly impossible to complete without Joshua Brahinsky's stalwart friendship as a long-term reading and writing partner, nor would it ever have begun without Sean and Milo Bakker Kellogg's constant care and companionship.

1. Names have been changed to protect the anonymity of research participants.

2. Syriac Orthodox Christians are known in different national, regional, and linguistic contexts as Suryoye (Suryoyo, singular masculine; Suryayto, singular feminine) or Suroyo in neo-Aramaic, Süryani in Arabic and Turkish, or Assyrian, Aramaean, or simply Syriac in English. In this corner of the Syriac world, where the majority of Syriac Orthodox Christians hail from Tur Abdin, little consensus exists over which term best captures the historical, cultural, and ethnonational dimensions of their identity in English or Dutch, so I default here to Suryoye / Suryoyo, with the understanding that this, too, is a contested term (see Bakker Kellogg 2019).

3. For more on the Syriac/Assyrian/Chaldean genocide, see David Gaunt, Naures Atto, and Soner O. Barthoma (2017).

4. I define theology as Christian ontology; that is, the broad field of debate among and within Christian traditions over the nature and purpose of reality. I generally refer to "theological politics" rather than to political theology to emphasize a more open discursive terrain where multiple theological currents within a polity may interact and influence each other. I understand secularism/secularity to emerge from within the interstitial spaces among discursive traditions, and among disparate scales of governance, where tensions over reproductive power are at stake. Semiotic ideology refers to "people's underlying assumptions about what signs are, what functions signs serve, and what consequences they might produce" in communication (Keane 2018, 64).

5. My approach to ethics charts a middle path among the semiotics of "everyday ethics" (e.g., Lambek 2010), the phenomenological (e.g., Throop 2009) and hermeneutic (e.g., Zigon 2013) orientations that emphasize freedom and "being-in-the-world," and those neo-Aristotelian perspectives that emphasize norms, traditions, and embodiment (e.g., Hirschkind 2006). Elsewhere, I develop this notion of "intersensorial ethics" to describe the foundational relation that structures human subjectivity, a relation that sustains itself because it is both linguistically mediated and pre-discursively embodied. 
6. Not all Moroccans or Dutch people of Moroccan descent are Arab or Arabic speakers, nor even, for that matter, Muslim. Many Dutch-Moroccan families identify not as Arab but as Amazigh, hailing originally from the Rif Mountains in Morocco, where the Tamazight language is preeminent over Arabic and the people are economically marginalized from the rest of Morocco (Amersfoort and Heelsum 2007).

7. Feminist and disability studies scholars have shown the link between trained bodily capacities for sensory perception and hegemonic power relations within a society. Sachi Sekimoto $(2018,87)$, for example, argues that "individuals incorporate social values and orientations into their bodies, as the embodied sensory orientations shape and inform their social and physical experiences."

8. In her study of ethical striving among Black Brazilian lesbicas, for example, Nessette Falu (2014) develops an expansive conception of "modes of freedom" as reformulating the self's relation to the self and to others by seeking recognition as an ethical subject against the grain of racial and sexual domination.

9. For a comparative example of this political genealogy in the contemporary Spanish context, where criteria for inclusion and exclusion are translated into the language of sentiment, rather than "norms and values," see Charles A. McDonald (2021).

10. As Stolcke (1993) reminds us, racism reinforces women's maternal role by naturalizing social inequalities. In capitalism, this naturalization reconciles equality of opportunity with inequality in reality; prior to and beyond capitalism, this naturalization reconciles any model of ethical personhood that poses reproductive power as a problem for the constitution of autonomous ethical subjects (see also Berg and Duyvendak 2012).

11. Anthropologists sometimes write about iconicity as if it is a characteristically un-Western and thus a potentially decolonial mode of meaning-making. Iconic meaning-making, in such conversations, is often juxtaposed with symbolic meaning-making, that is, the semiotic process based on arbitrary linguistic signs, which scholars also sometimes characterize as constitutively modern and secular (e.g., Meyer 2009, 5, 43). As Angie Heo (2018) shows, however, iconicity can saturate modernist sociopolitical imaginaries and exacerbate identitarian divisions, as it does among Egyptian Copts and Muslims, where one may implicitly participate in iconicity's semiotic logic without explicitly espousing Orthodox Christian doctrine about icons.

12. Looking beyond Europe, Adeola Oni-Orisan (2017) similarly argues that a secularism formed through complex tensions among liberal and Pentecostal Christian traditions shapes the biopolitical field where racialization, maternal health, development discourse, and reproductive desire intersect in postcolonial Nigeria.

13. Such ethics include the ritual mourning practices of the day after Easter, but they also include patriarchal norms for intergenerational communication, which are saturated with ecclesiastical significance and run against the grain of secular sexual ethics.

14. Ethnographic studies of Dutch cosmopolitan nationalism have diagnosed a gap between what Oskar Verkaaik and Pooyan Tamimi Arab (2016) term "constitutionalist secularism" and "culturalist secularism." In this formulation, secular political practices, cultural self-images, and perceptions of religious difference prove equally integral to Dutch attitudes toward immigration in both official commitments to pluralism and its nativist rejection. These practices and self-images rest on the hard-won discursive silence around both "religion" and "race" (Essed and Trienekens 2008; Tamimi Arab 2012; Wekker 2004). Driven from both the top down and the bottom up after World War II, political leaders worked to eradicate anti-Semitism and colonial racism by eliminating "race" as an official category, while Dutch religious culture was transformed by the swift and widespread rejection of pillarization (Houkes 2009).

15. In the Netherlands as in much of Europe, "social pedagogy" is both a field of research and a professional practice akin to "social work" in the United States, with some significant differences that lie beyond the scope of this article.

16. One of the many functions of St. Ephrem's Monastery, for example, was to serve as the Dutch-German Suryoye's living room, where extended families congregated regularly to 
visit each other and their cloistered aunts, uncles, and cousins, and to seek the bishop's pastoral counsel for family crises.

\section{REFERENCES}

Althusser, Louis

1970 “Ideology and Ideological State Apparatuses: Notes Towards and Investigation." In Lenin and Philosophy and Other Essays, 127-86. New York: Monthly Review.

Amersfoort, Hans van, and Anja van Heelsum

2007 "Moroccan Berber Immigrants in The Netherlands, Their Associations and Transnational Ties: A Quest for Identity and Recognition.” Immigrants and

Arendt, Hannah Minorities 25, no. 3: 234-62. https://doi.org/10.1080/02619280802407343.

2004 The Origins of Totalitarianism. New York: Schocken Books. Originally published in 1968.

Arkin, Kimberly A.

2013 Rhinestones, Religion, and the Republic: Fashioning Jewishness in France. Stanford, Calif.: Stanford University Press.

Armbruster, Heidi

2014 "Linked Biographies in Changing Times: Syriac Christians in Vienna." Ethnologie francaise 3, no. 44: 469-78. https://doi.org/10.3917/ethn.143.0469.

Asad, Talal

1993 Genealogies of Religion: Discipline and Reasons of Power in Christianity and Islam. Baltimore, Md.: Johns Hopkins University Press.

2003 Formations of the Secular: Christianity, Islam, Modernity. Stanford, Calif.: Stanford University Press.

Atto, Naures

2011 Hostages in the Homeland, Orphans in the Diaspora: Identity Discourses among the Assyrian/Syriac Elites in the European Diaspora. Leiden: Leiden University Press.

Bakker Kellogg, Sarah

2015 "Ritual Sounds, Political Echoes: Vocal Agency and the Sensory Cultures of Secularism in the Dutch Syriac Diaspora." American Ethnologist 42, no. 3: 431-45. https://doi.org/10.1111/amet.12139.

2018 "Worlds within Worlds: On Imperial Christianity's Illegible Internal Others." New Directions in the Anthropology of Christianity. https://www.new-directions.sps. ed.ac.uk/praying-with-the-senses-review-forum-sarah-bakker-kellogg/.

2019 "Perforating Kinship: Syriac Christianity, Ethnicity, and Secular Legibility." Current Anthropology 60, no. 4: 475-98. https://www.journals.uchicago.edu/doi/

Balkenhol, Markus abs/10.1086/705233.

2014 Tracing Slavery: An Ethnography of Diaspora, Affect, and Cultural Heritage in Amsterdam. Amsterdam: Vrije Universiteit Amsterdam Press.

2016 "Silence and the Politics of Compassion: Commemorating Slavery in the Netherlands." Social Anthropology 24, no. 3: 278-93. https://doi.org/10.1111/14698676.12328 .

Balkenhol, Markus, and Katharina Schramm

2019 "Doing Race in Europe: Contested Pasts and Contemporary Practices." Social Anthropology 27, no. 4: 585-93. https://doi.org/10.1111/1469-8676.12721.

Berg, Marguerite van den, and Jan Willem Duyvendak

2012 "Paternalizing Mothers: Feminist Repertoires in Contemporary Dutch Civilizing Offensives." Critical Social Policy 32, no. 4: 556-76. https://doi.

Berzon, Todd S. org/10.1177\%2F0261018312439360.

2016 Classifying Christians: Ethnography, Heresiology, and the Limits of Knowledge in Late Antiquity. Berkeley: University of California Press. 
Blom, J.C.H., and J. Talsma, eds.

2000 De verzuiling voorbij: Godsdienst, stand en natie in de lange negentiende eeuw. Amsterdam: Het Spinhuis.

Bracke, Sarah

2013 “Transformations of the Secular and the 'Muslim Question': Revisiting the Historical Coincidence of Depillarisation and the Institutionalisation of Islam in the Netherlands." Journal of Muslims in Europe 2, no. 2: 208-26. https://doi.

Bridges, Khiara org/10.1163/22117954-12341264.

2011 Reproducing Race: An Ethnography of Pregnancy as a Site of Racialization. Berkeley: University of California Press.

Brink, Gabriel van den

2004 Schets van een beschavingsoffensief: Over normen, normaliteit, en normalisatie in Nederland. Amsterdam: Wetenschappelijk Raad voor het Regeringsbeleid.

Buell, Denise Kimber

2005 Why This New Race: Ethnic Reasoning in Early Christianity. New York: Columbia University Press.

Coenders, Yannick, and Sébastien Chauvin

2017 "Race and the Pitfalls of Emotional Democracy: Primary Schools and the Critique of Black Pete in the Netherlands." Antipode 49, no. 5: 1244-62. https://doi. org/10.1111/anti.12328.

Connolly, William E.

1999 Why I Am Not a Secularist. Minneapolis: University of Minnesota Press.

Davis, Dána-Ain

2019 Reproductive Injustice: Racism, Pregnancy, and the Premature Birth. New York: New York University Press.

Duyvendak, Jan Willem, Peter Geschiere, and Evelien Tonkens

2016 The Culturalization of Citizenship: Belonging and Polarization in a Globalizing World. London: Palgrave Macmillan.

Essed, Philomena, and Sandra Trienekens

2008 “'Who wants to feel white?' Race, Dutch Culture and Contested Identities." Ethnic and Racial Studies 31, no. 1: 52-72. https://doi.org/10.1080/01419870701538885.

Falu, Nessette

2014 'Lèsbicas Negras' Ethics and the Scales of Racialized Sexual Recognitions in Fanon, Frantz Gynecology and Public Discourses in Salvador-Bahia.” PhD diss., Rice University.

2008 Black Skin, White Masks. Translated by Richard Philcox. New York: Grove Press. Originally published in 1952.

Fernando, Mayanthi L.

2014 "Intimacy Surveilled: Religion, Sex, and Secular Cunning." Signs 39, no. 3: 685708. https://doi.org/10.1086/674207.

Gaunt, David, Naures Atto, and Soner O. Barthoma, eds.

2017 Let Them Not Return: Sayfo — The Genocide against the Assyrian, Syriac, and Chaldean Christians in the Ottoman Empire. Oxford: Bergahn.

Geschiere, Peter

2009 The Perils of Belonging: Autochthony, Citizenship, and Exclusion in Africa and Europe.

Ghorashi, Halleh Chicago: University of Chicago Press.

2010 "From Absolute Invisibility to Extreme Visibility: Emancipation Trajectory of Migrant Women in the Netherlands." Feminist Review 94, no. 1: 75-92. https://doi.

Griffith, Sidney H. org/10.1057\%2Ffr.2009.38.

2008 The Church in the Shadow of the Mosque: Christians and Muslims in the World of Islam. Princeton, N.J.: Princeton University Press. 
Gross, Simcha

2020 "A Long Overdue Farewell: The Purported Jewish Origins of Syriac Christianity." Jews and Syriac Christians: Intersections across the First Millennium, edited by Aaron Michael Butts and Simcha Gross, 121-44. Tubingen, Germany: Mohr Siebeck.

Hage, Ghassan

2010 "The Affective Politics of Racial Mis-interpellation.” Theory, Culture, and Society 27, no. 7/8: 112-29. https://doi.org/10.1177\%2F0263276410383713.

Hager, Anna

2020 "When Ephrem Meets the Maya: Defining and Adapting the Syriac Orthodox Tradition in Guatamala." Hugoye: Journal of Syriac Studies 23, no. 2: 215-62. https://hugoye.bethmardutho.org/article/hv23n2hager.

Heo, Angie

2018 The Political Lives of Saints: Christian-Muslim Mediation in Egypt. Berkeley: University of California Press.

Hirschkind, Charles

2006 The Ethical Soundscape: Cassette Sermons and Islamic Counterpublics. New York: Columbia University Press.

Holmes, Douglas R.

2000 Integral Europe: Fast-Capitalism, Multiculturalism, Neofascism. Princeton, N.J.: Princeton University Press.

Houkes, Annemarie

2009 Christelijke vaderlanders: Godsdienst, burgerschap en de Nederlandse natie (1850-1900). Amsterdam: Wereldbibliotheek.

Husain, Atiya

2017 "Retrieving the Religion in Racialization: A Critical Review." Sociology Compass 11, no. 9: e12507. https://doi.org/10.1111/soc4.12507.

Jarjour, Tala

2018 Sense and Sadness: Syriac Chant in Aleppo. Oxford: Oxford University Press.

Jennings, Willie James

2010 The Christian Imagination: Theology and the Origins of Race. New Haven, Conn.: Yale University Press.

Keane, Webb

2007 Christian Moderns: Freedom and Fetish in the Mission Encounter. Berkeley: University of California Press.

2018 "On Semiotic Ideology." Signs and Society 6, no. 1: 64-87. https://doi. org/10.1086/695387.

Kennedy, James

1995 "Building New Babylon: Cultural Change in the Netherlands during the 1960s." PhD diss., University of Iowa.

Khabeer, Su'ad Abdul

2017 "Citizens and Suspects: Race, Gender, and the Making of American Muslim Citizenship." Transforming Anthropology 25, no. 2: 103-19. https://doi.org/10.1111/ traa.12098.

Khan, Aisha

2004 Callaloo Nation: Metaphors of Race and Religious Identity among South Asians in Trinidad. Durham, N.C.: Duke University Press.

Kiraz, George Anton

2019 The Syriac Orthodox in North America (1895-1995): A Short History. Piscataway, N.J.: Gorgias Press.

Koning, Martijn de

2016 “'You need to present a counter-message': The Racialisation of Dutch Muslims and Anti-Islamophobia Initiatives." Journal of Muslims in Europe 5, no. 2: 170-89.

Kuyper, Abraham https://doi.org/10.1163/22117954-12341325/.

1943 Calvinism: Six Stone Foundation Lectures. Grand Rapids, Mich.: Eerdmans. 
Lambek, Michael

2010 "Toward an Ethics of the Act." In Ordinary Ethics: Anthropology, Language, and Action, edited by Michael Lambek, 39-63. New York: Fordham University Press.

2015 “Living As If It Mattered.” In Four Lectures on Ethics: Anthropological Perspectives, edited by Michael Lambek, Veena Das, Didier Fassin, and Webb Keane, 5-51.

Lechner, Frank J. Chicago: Hau Books.

1999 "Managing Others: Minorities Policy and National Identity in the Netherlands." Halle Institute occasional paper, Claus M. Halle Institute for Global Learning, Emory, Atlanta.

2008 The Netherlands: Globalization and National Identity. New York: Routledge.

Lukasik, Candace

2020 "Postcolonial Solidarities: Oriental Orthodox Kinship in an Age of Migration." Journal of Ecumenical Studies 55, no. 4: 484-517. https://doi.org/10.1353/ ecu.2020.0043.

2021 "Economy of Blood: The Persecuted Church and the Racialization of American Copts." American Anthropologist. Published ahead of print, May 16. https://doi. org/10.1111/aman.13602.

Mack, Jennifer

2017 The Construction of Equality: Syriac Immigration and the Swedish City. Minneapolis: Minnesota University Press.

Markell, Patchen

2003 Bound by Recognition. Princeton, N.J.: Princeton University Press.

Martínez, María Elena

2008 Genealogical Fictions: Limpieza de Sangre, Religion, and Gender in Colonial Mexico. Stanford, Calif.: Stanford University Press.

McAllister, Carol, and Valentina Napolitano

2020 "Introduction: Incarnate Politics beyond the Cross and the Sword." Social Analysis 64, no. 4: 1-20. https://doi.org/10.3167/sa.2020.640401.

McDonald, Charles A.

2021 "Rancor: Sephardi Jews, Spanish Citizenship, and the Politics of Sentiment." Comparative Studies in Society and History 63, no. 3: 722-51. https://doi.org/10.1017/ S0010417521000190.

M'charek, Amade

2008 "Silent Witness, Articulate Collective: DNA Evidence and the Inference of Visible Traits." Bioethics 22, no. 9: 519-28. https://doi.org/10.1111/j.14678519.2008.00699.x.

2013 "Beyond Fact or Fiction: On the Materiality of Race in Practice." Cultural Anthropology 28, no. 3: 420-42. https://doi.org/10.1111/cuan.12012.

M'charek, Amade, Katharina Schramm, and David Skinner

2014 "Technologies of Belonging: The Absent Presence of Race in Europe." Science, Technology, and Human Values 39, no. 4: 459-67. https://doi.

Mepschen, Paul org/10.1177\%2F0162243914531149.

2016 "Everyday Autochthony: Difference, Discontent and the Politics of Home in Meyer, Birgit Amsterdam.” PhD diss., University of Amsterdam.

2009 Aesthetic Formations: Media, Religion, and the Senses. New York: Palgrave MacMillan. Miller, J. Reid

2017 Stain Removal: Ethics and Race. Oxford: Oxford University Press.

Mondzain, Marie-José

2005 Image, Icon, Economy: The Byzantine Origins of the Contemporary Imaginary. Stanford, Calif.: Stanford University Press. 
Mullings, Leith, and Alaka Wali

2001 Stress and Resilience: The Social Context of Reproduction in Central Harlem. New York: Kluwer.

Oliphant, Elayne

2020 The Privilege of Being Banal: Art, Secularism, and Catholicism in Paris. Chicago: University of Chicago Press.

Oni-Orisan, Adeola

2017 "Church and (Re)birth: Legacies of Christianity for Maternal Care in Nigeria." Oostindie, Gert Transforming Anthropology 25, no. 2: 120-29. https://doi.org/10.1111/traa.12099.

2009 Postkoloniaal Nederland: Vijfenzestig jaar Vegeten, herdenken, verdringen. Amsterdam: Bert Bakker.

Özdil, Zihni

2014 "Racism is an American problem': Dutch Exceptionalism and the Politics of Denial.” Frame 27, no. 2: 49-64. https://www.frameliteraryjournal.com/27-2racism-in-the-netherlands/1429/.

Özyürek, Esra

2015 Being German, Becoming Muslim: Race, Religion, and Conversion in the New Europe. Princeton, N.J.: Princeton University Press.

Ratzinger, Joseph (Pope Benedict XVI)

2007 Europe: Today and Tomorrow. San Francisco: Ignatius.

Reekum, Rogier van, and Jan Willem Duyvendak

2012 "Running from Our Shadows: The Performative Impact of Policy Diagnoses in Dutch Debates on Immigrant Integration.” Patterns of Prejudice 46, no. 5: 445-66.

Roberts, Dorothy https://doi.org/10.1080/0031322X.2012.718164.

2017 Killing the Black Body: Race, Reproduction, and the Meaning of Liberty. New York: Vintage Books. Originally published in 1997.

Rogozen-Soltar, Mikaela H.

2017 Spain Unmoored: Migration, Conversion, and the Politics of Islam. Bloomington: Indiana University Press.

Schie, Gerwin van

2018 "Origins: A History of Race-Ethnic Categorisation in the Dutch Governmental Data Ontology (1899-2018).” TMG Journal for Media History 21, no. 2: 67-88. http://doi.org/10.18146/2213-7653.2018.367.

Schmoller, Andreas, ed.

2018 Middle Eastern Christians and Europe: Historical Legacies and Present Challenges. Zurich: Lit Verlag.

Sekimoto, Sachi

2018 "Race and the Senses: Toward Articulating the Sensory Apparatus of Race." Critical Philosophy of Race 6, no. 1: 82-100. https://doi.org/10.5325/critphilrace.6.1.0082.

Seremetakis, C. Nadia

1994 The Senses Still: Perception and Memory as Material Culture in Modernity. Chicago: University of Chicago Press.

Shange, Savannah

2019 Progressive Dystopia: Abolition, Antiblackness, and Progressive Schooling in San Francisco. Durham, N.C.: Duke University Press.

Stolcke, Verena

1993 “Is Sex to Gender as Race Is to Ethnicity?" Gendered Anthropology, edited by Teresa

Stoler, Ann Laura del Valle, 17-37. London: Routledge.

1995 Race and the Education of Desire: Foucault's History of Sexuality and the Colonial Order

Stoller, Paul of Things. Durham, N.C.: Duke University Press.

1997 Sensuous Scholarship. Philadelphia: University of Pennsylvania Press. 
Tamarkin, Noah

2014 "Genetic Diaspora: Producing Knowledge of Genes and Jews in Rural South Africa." Cultural Anthropology 29, no. 3: 552-74. https://doi.org/10.14506/ ca29.3.06.

Tamimi Arab, Pooyan

2012 “(Dis)Entangling Culturalism, Nativism, Racism.” Krisis 2012, no. 2: 68-74. https://archive.krisis.eu/?page_id=53.

2017 Amplifying Islam in the European Soundscape: Religious Pluralism and Secularism in the Netherlands. London: Bloomsbury.

Throop, C. Jason

2009 “Becoming beautiful in the dance': On the Formation of Ethical Modalities of Being in Yap, Federated States of Micronesia.” Oceania 79, no. 2: 179-201. https:// doi.org/10.1002/j.1834-4461.2009.tb00058.x.

Topolski, Anya

2018 "The Race-Religion Constellation: A European Contribution to the Critical Philosophy of Race." Critical Philosophy of Race 6, no. 1: 58-81. https://muse.jhu. edu/article/683044.

Turman, Eboni Marshall

2013 Toward a Womanist Ethic of Incarnation: Black Bodies, the Black Church, and the Council of Chalcedon. New York: Palgrave Macmillan.

Verkaaik, Oskar, and Pooyan Tamimi Arab

2016 "Managing Mosques in the Netherlands: Constitutional versus Culturalist Secularism." Journal of Muslims in Europe 5, no. 2: 251-68. https://doi. org/10.1163/22117954-12341331.

Vlasblom, Dirk

2017 "Hoe sorteren van de soort uitdraaide op rassenwaan." NRC Handeslblad, Dossier: Racisme. https://www.nrc.nl/nieuws/2017/11/17/hoe-sorteren-van-de-soortuitdraaide-op-rassenwaan-14075192-a1581607.

Wekker, Gloria

2004 "Still Crazy after All Those Years . . . : Feminism for the New Millennium." European Journal of Women's Studies 11, no. 4: 487-500. https://doi. org/10.1177\%2F1350506804046822.

2016 White Innocence: Paradoxes of Colonialism and Race. Durham, N.C.: Duke University Press.

Weltecke, Dorothea

2016 "Bar 'ebroyo on Identity: Remarks on His Historical Writing." Hugoye: Journal of Syriac Studies 19, no. 2: 303-32. https://www.degruyter.com/document/ doi/10.31826/9781463240028-007/html.

Yanow, Dvora, and Marleen van der Haar

2013 "People out of Place: Allochthony and Autochthony in the Netherlands' Identity Discourse - Metaphors and Categories in Action.” Journal of International Relations and Development 16: 227-61. https://doi.org/10.1057/jird.2012.13.

Zigon, Jarrett

2013 “On Love: Remaking Moral Subjectivity in Postrehabilitation Russia." American Ethnologist 40, no. 1: 201-15. https://doi.org/10.1111/amet.12014. 